\title{
Cloning of genes associated with the colonization of tomato roots by the arbuscular mycorrhizal fungus Glomus mosseae
}

\author{
A Tahiri-Alaoui*, JF Antoniw \\ IACR-Rothamsted, Crop and Disease Management Department, Harpenden, Hertfordshire AL5 2JQ, UK
}

(Received 30 July 1996; accepted 23 September 1996)

\begin{abstract}
Summary - Complimentary DNA (cDNA) libraries were made from RNA isolated from uninoculated (control) tomato roots and tomato roots colonized with arbuscular mycorrhizal fungus Glomus mosseae. Four clones of genes upregulated, and one clone of a gene downregulated by $G$ mosseae colonization of roots were isolated by differential screening. Partial sequencing of the cDNA clones revealed that the upregulated clones showed significant similarities to the following genes: a phosphoenolpyruvate carboxylase gene from nodules of alfalfa, a human cullin gene, a nematodeinduced gene in giant cells of tomato roots and a mannitol dehydrogenase gene from celery and parsley. The clone of the repressed gene did not show any significant similarity to known sequences in the databases.
\end{abstract}

arbuscular mycorrhiza / Glomus mosseae / gene cloning / root / tomato

Résumé - Clonage de gènes associés à la colonisation des racines de tomates par le champignon mycorhizogène arbusculaire Glomus mosseae. Une banque d'ADN complémentaire (ADNc) a été construite à partir d'ARN messagers isolés de racines non inoculées (témoin) et de racines colonisées avec le champignon mycorhizogène arbusculaire Glomus mosseae. Quatre clones de gènes surexprimés et d'un gène réprimé suite à la colonisation des racines par $G$ mosseae ont été isolés par criblage différentiel. Le séquençage partiel des clones d'ADNc a révélé que ceux surexprimés présentent des similitudes significatives avec les gènes suivants : un gène de phosphénolpyruvate carboxylase des nodules de luzerne, un gène de "cullin» humain, un gène induit dans les cellules géantes des racines de tomate infectées par des nématodes et un gène de la mannitol déshydrogénase de céleri et de persil. Le clone du gène réprimé ne montre aucune similitude significative avec des séquences connues dans les bases de données.

mycorhizes arbusculaires / Glomus mosseae / clonage de gènes / racines / tomate

* Correspondence and reprints 


\section{INTRODUCTION}

An important feature of symbiotic arbuscular mycorrhizal (AM) fungi is their consistent association with roots of most plant genera (Newman and Reddell, 1987). The fungal partner colonizes predominantly the root cortex and bidirectional exchange of nutrients between partners occurs across a specialized interface formed between finely differentiated intracellular haustoria called arbuscules and the plant protoplast (Harley and Smith, 1983). The AM association is a beneficial interaction for both plant and fungus, and represents a universal model for analyzing molecular mechanisms involved in the control of a symbiotic state, as well as for studying more general fungal-root interactions. Despite extensive colonization of root tissues by the fungal partner, the host plant seems to exert some control over hyphal proliferation which is confined to cells of the parenchyma. The possibility that defence mechanisms, comparable to those activated in fungalpathogenic interactions, may also be implicated in $A M$ interactions has recently been the subject of several investigations (for review see Vivienne-Gianinazzi et al, 1996). All the studies on the spatiotemporal expression of defencerelated genes seem to indicate that AM fungi can activate part of the plant's metabolic pathways associated with defence processes but in a weak, transient and very localized fashion.

Litte is known about genes which are specifically induced, from either partners, during arbuscular mycorrhiza symbiosis. Evidence for differential gene expression in wild-type and $\mathrm{myc}^{-1}$ mutant pea roots interacting with $G$ mosseae has been obtained using differential display reverse transcription-polymerase chain reaction (RTPCR) (Martin-Laurent et al, 1995). Recently, using a targeted approach, Harrison (1996) isolated a cDNA clone encoding a hexose transporter of plant origin from a cDNA library prepared from Medicago truncatula roots colonized by the mycorrhizal fungus Glomus versiforme. Furthermore, Harrison and Van Buuren (1996) reported the isolation of a cDNA clone of fungal origin encoding a phosphate transporter.

The aim of this work was to identify up- or downregulated genes in tomato (Lycopersicon esculentum cv Early Mech) roots colonized by the AM fungus Glomus mosseae. The strategy used was based on non-targeted differential screening of CDNA libraries from AM-colonized and control roots to identify and clone genes from either partners whose expression is specifically modulated during the interaction. In this paper, we report results on the identification and cloning of five cDNA clones probably of plant origin. Four of these clones represented upregulated genes during the $A M$ association and showed significant similarities to known sequences in the sequence databases. One clone represented a downregulated gene which had no significant similarity with other sequences in the sequence databases.

\section{MATERIALS AND METHODS}

\section{Plant cultures and inoculation with $A M$ fungus}

Surface disinfected seeds of Lycopersicon esculentum cv Early Mech were pre-germinated for 3 to 5 days on humidified and sterile sand in petri dishes. The germinated seeds were then planted on sterile expanded clay. The inoculation with $G$ mosseae (LPA21) was done immediately before planting with chopped roots (1 g per bottle) of mycorrhizal leek plants stratified 1-2 $\mathrm{cm}$ below the plantlets. The control plants were planted under the same conditions without arbuscular mycorrhiza. The pots were placed in a growth chamber $\left(22^{\circ} / 24{ }^{\circ} \mathrm{C}, 16 \mathrm{~h}\right.$ photoperiod, $300 \mu \mathrm{mol} \mathrm{m} \mathrm{m}^{-2}, \mathrm{~s}^{-1}, 70 \%$ relative humidity). The plants were watered on alternate days with Long Ashton nutrient solution containing $32 \mu \mathrm{M} \mathrm{KH}{ }_{2} \mathrm{PO}_{4}$.

\section{RNA extraction}

Seven-week-old control tomato roots and tomato roots that were heavily colonized by $G$ mosseae as assessed by trypan blue staining (Trouvelot et al, 1985) were washed with running tap water and distilled water, blotted dry and ground in liquid nitrogen until a fine powder was obtained. Low $\mathrm{pH}$ (5.5) phenol/chloroform/isoamyl alcohol (25:25:1) was added to the powder and grinding continued for $5 \mathrm{~min}$. The extraction buffer (Gurr and McPherson, 1992) containing $8 \mathrm{M}$ guanidinium- $\mathrm{HCl}, 20 \mathrm{mM}$ Mes, $20 \mathrm{mM}$ EDTA, adjusted to $\mathrm{pH} 7.0$ with $\mathrm{NaOH}, 50 \mathrm{mM}$ 2-mercaptoethanol, was added and grinding continued for $5 \mathrm{~min}$ more. The homogenate was centrifuged to separate the aqueous and phenol phases. The upper aqueous phase was re-extracted up to five times with phenol/chloroform until the interface between the aqueous and the phenol phases was clean. Total RNA was then precipitated overnight at $-20^{\circ} \mathrm{C}$ with 0.2 volume $1 \mathrm{M}$ acetic acid and 0.7 volume cold absolute ethanol. The RNA was then pelleted at $10000 \mathrm{~g}$ at $4{ }^{\circ} \mathrm{C}$ for $30 \mathrm{~min}$, and the pellet washed with $0.5 \mathrm{~mL}$ $3 \mathrm{M} \mathrm{Na}$-acetate $\mathrm{pH} 5.5$ to remove low molecular weight RNA species and polysaccharides. At this stage the RNA was still contaminated with DNA so an additional step involving precipitation for $5 \mathrm{~h}$ on ice with $4 \mathrm{M} \mathrm{LiCl}$ 
was included. The quantity and integrity of RNA was assessed spectrophotometrically and by electrophoresis in agarose native gels.

\section{cDNA libraries and screening}

$\mathrm{PolyA}^{+}$mRNA was prepared using an Oligotex spin column kit (Qiagen Ltd, UK) according to the protocol provided by the supplier. The cDNA libraries from control and Glomus mosseaecolonized roots were prepared in the Lambda Zap XR vector (Stratagene Ltd, Cambridge, UK) using a Uni-Zap cDNA kit and the protocol provided by the supplier. The primary libraries obtained were titred and subsequently amplified to make a high-titre stock of each library. The sizes of the cDNA inserts in the Lambda vector were estimated by PCR using the $T_{3}$ and $T_{7}$ primers (Gurr and McPherson, 1992).

The libraries were screened by differential hybridization of identical plaque lifts (Sambrook et al, 1989) using as probe [ $\left.{ }^{32} \mathrm{P}\right]$-labelled first strand CDNA made from total polyA+ RNA isolated from control or mycorrhizal roots. Differentially detected phage clones were used as template for PCR-based screening with either $T_{3}$ and $T_{7}$ or $M_{13}$ forward and reverse primers in order to determine the purity of the clones as well as the size of cDNA inserts. The PCR products obtained were divided into two equal aliquots, separated in agarose gels and transferred onto nylon membranes. Southern blot analysis was used to detect differentially expressed clones by probing the membranes with [32P]-labelled first strand cDNA made from total polyA ${ }^{+}$ RNA isolated from control or mycorrhizal roots. Differentially detected phage clones were submitted to in vivo excision of the pBluescript phagemid as recommended by the manufacturer (Stratageme Ltd, Cambridge, UK). The plasmid containing differentially expressed or repressed cDNA inserts were sequenced using the $A B I$ dye terminator cycle sequencing ready reaction kit. Clones were sequenced from their 5' and 3 ' ends; the resulting sequences were compared to each other and to sequences present in the Genbank and EMBL databases using the Genetics Computer Group software package.

\section{RESULTS}

The colonization of tomato roots with $G$ mosseae was assessed after 5 weeks of inoculation by staining the roots with trypan blue. At this stage of inoculation the roots were heavily colonized with an intensity of infection estimated at $72 \%$, and an arbuscular frequency of $69 \%$. PolyA ${ }^{+}$ mRNAs were extracted at this stage from colonized tomato and from control roots of the same age, and used to synthesize cDNAs and construct the two libraries. The titres of the cDNA libraries obtained were $3.0 \times 10^{6}$ and $1.2 \times 10^{6}$ for the library prepared from tomato roots colonized by the mycorrhizal fungus $G$ mosseae and for control roots, respectively.

\section{Differential screening}

The libraries were differentially screened with first strand cDNA derived from the same RNA samples as those from which the libraries were constructed. After a first round of screening, 58 independent clones out of one million phage screened were isolated from the AM library. These clones represented genes theoretically upregulated in tomato roots during AM association. Similarly, to isolate genes which might be repressed during $A M$ association the control library was differentially screened, and six phage clones isolated out of 500000 screened. Because of the high plating density of the phages screened in both libraries, the majority of the isolated clones were contaminated by the surrounding phages. This was obvious after a PCR amplification of the cDNA inserts with $M_{13}$ forward and reverse primers. The PCR products showed several bands on ethidium bromide-stained agarose gels (results not shown). Because of the large number of phage clones isolated from the AM library and the time it would take to screen all of them individually, only the clones which gave the strongest signals on the autoradiographs were examined further. After second and sometimes a third round of screening, ten independent clones were isolated from single phages of the AM library. A typical example of the isolation of an upregulated gene from the AM library is shown on the autoradiograph of replica filters in figure 1. The phage isolated from the plate corresponding to this autoradiograph was obtained as a single clone after only two rounds of screening (fig $1 \mathrm{~A}$ ). Other clones were equally detected by both control and AM-colonized root CDNA probes; these represented constitutively expressed genes which seemingly were not altered during AM association (fig $1 \mathrm{~A}, \mathrm{~B}$ ).

Only one single phage clone from the control library survived the second and third rounds of screening (fig 2). The isolated phage should represent a repressed gene because it was detected in the control library which was constructed from RNA isolated from uninoculated tomato roots. This clone hybridized with radiolabelled first strand cDNA prepared from RNA isolated from uninoculated tomato roots (fig $2 B$ ), whereas first strand CDNA prepared from RNA isolated from 


\section{Isolation of induced genes}
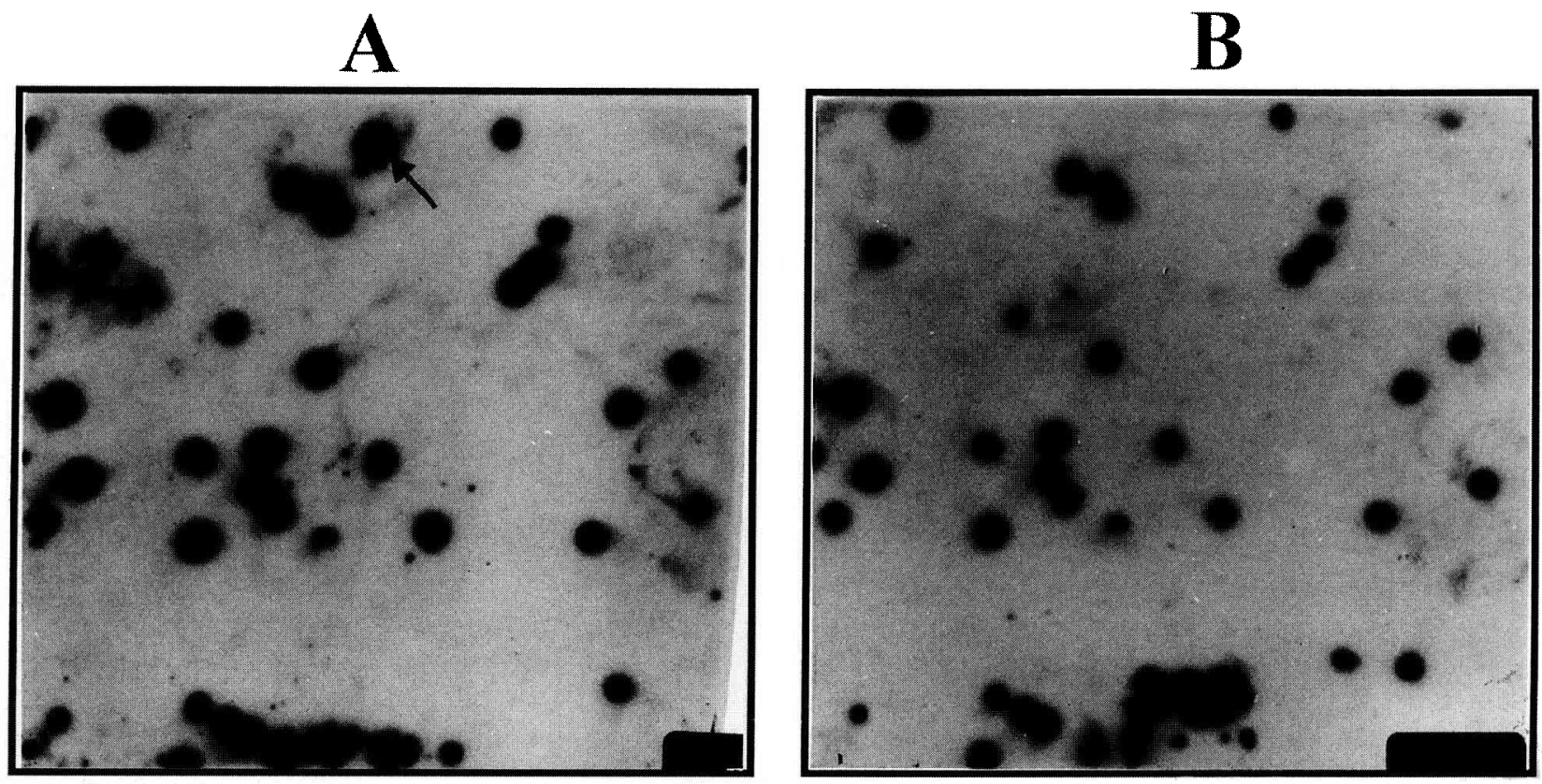

Fig 1. A typical example of differential hybridization of ${ }^{32}$-labelled first strand cDNA probes to a sample of mycorrhizal cDNA library from tomato roots. $\mathbf{A}$ and $\mathbf{B}$ are replica filters lifted from a single plate and hybrized with cDNA probes synthesized using RNA from arbuscular mycorrhizal-colonized and uninoculated tomato roots, respectively. The arrow denotes the plaque corresponding to the putatively upregulated cloned gene isolated for further analysis.

\section{Isolation of repressed genes}

A

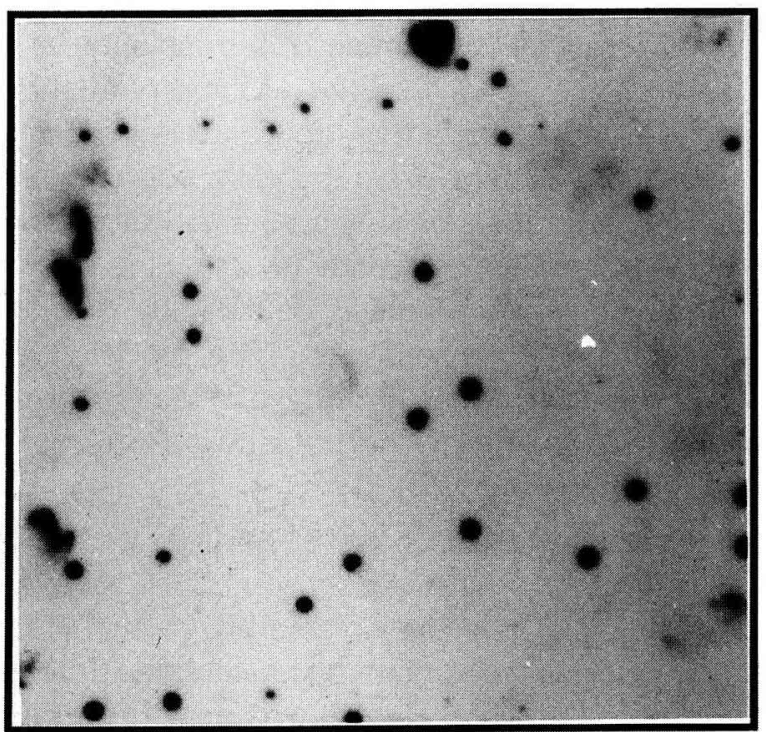

B

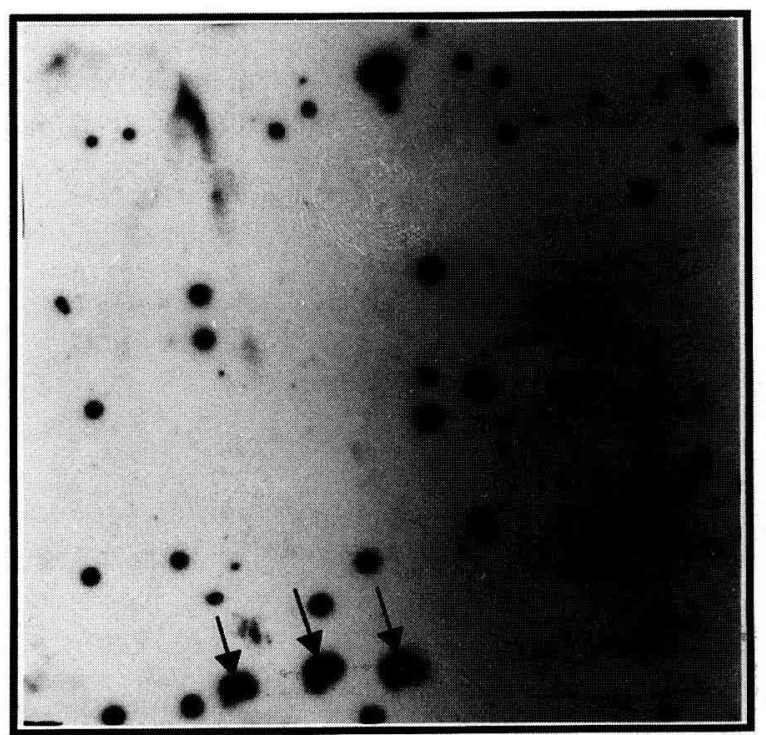

Fig 2. A typical example of differential hybridization of ${ }^{32}$ P-labelled first strand cDNA probes to a sample of $c$ DNA library from uninoculated tomato roots (control). A and $\mathbf{B}$ are replica filters lifted from a single plate and hybrized with cDNA probes synthesized using RNA from arbuscular mycorrhizal-colonized and uninoculated tomato roots, respectively. The arrows denote the plaques corresponding to the putatively downregulated cloned genes isolated for further analysis. 
AM-colonized roots did not hybridize with it (fig 2A). Although there were three differentially hybridizing plaques (fig 2B), further analysis showed that they were all identical.

\section{PCR-based screening}

At this stage a PCR-based screening strategy was adopted. This involved the use of an aliquot from each single phage clone as template for a PCR reaction using $M_{13}$ forward and reverse primers to amplify the cDNA insert within the polycloning site. There are four advantages to using this approach: i) it showed whether the phage clone was single or contaminated, ii) it provided an estimate of the size of the inserted cDNA, iii) several phage clones could be screened at once, iv) when combined with Southern blotting analysis it provided an additional check of the induction or repression of the clones under investigation. An example of PCR products analyzed in an ethidium bromide- stained agarose gel is illustrated in figure $3 \mathrm{~A}$. Nine out of ten phage clones differentially screened from the AM-colonized tomato root library gave strong single bands but the clone in track eight gave two PCR products with very different molecular weights. The majority of the bands had different sizes which indicated that the corresponding cDNA inserts were all different from each other. However, it was also possible that some of them could be identical clones but with different lengths. The faint bands revealed on the gel were non-specific PCR products, probably due to the low annealing temperature used during the amplification. Equal aliquots of the same PCR products were separated on the same gel and transferred onto a nylon membrane to make replica filters which were hybridized with radiolabelled first strand cDNA prepared from RNA isolated from AM-colonized (fig 3B) or control roots (fig $3 C$ ). The autoradiographs revealed qualitative and quantitative differences in the hybridization signals. The major bands from clones 1,2 and 8 showed a strong hybridization signal with CDNA probes derived from AM-colo-

\section{Isolation of induced genes}

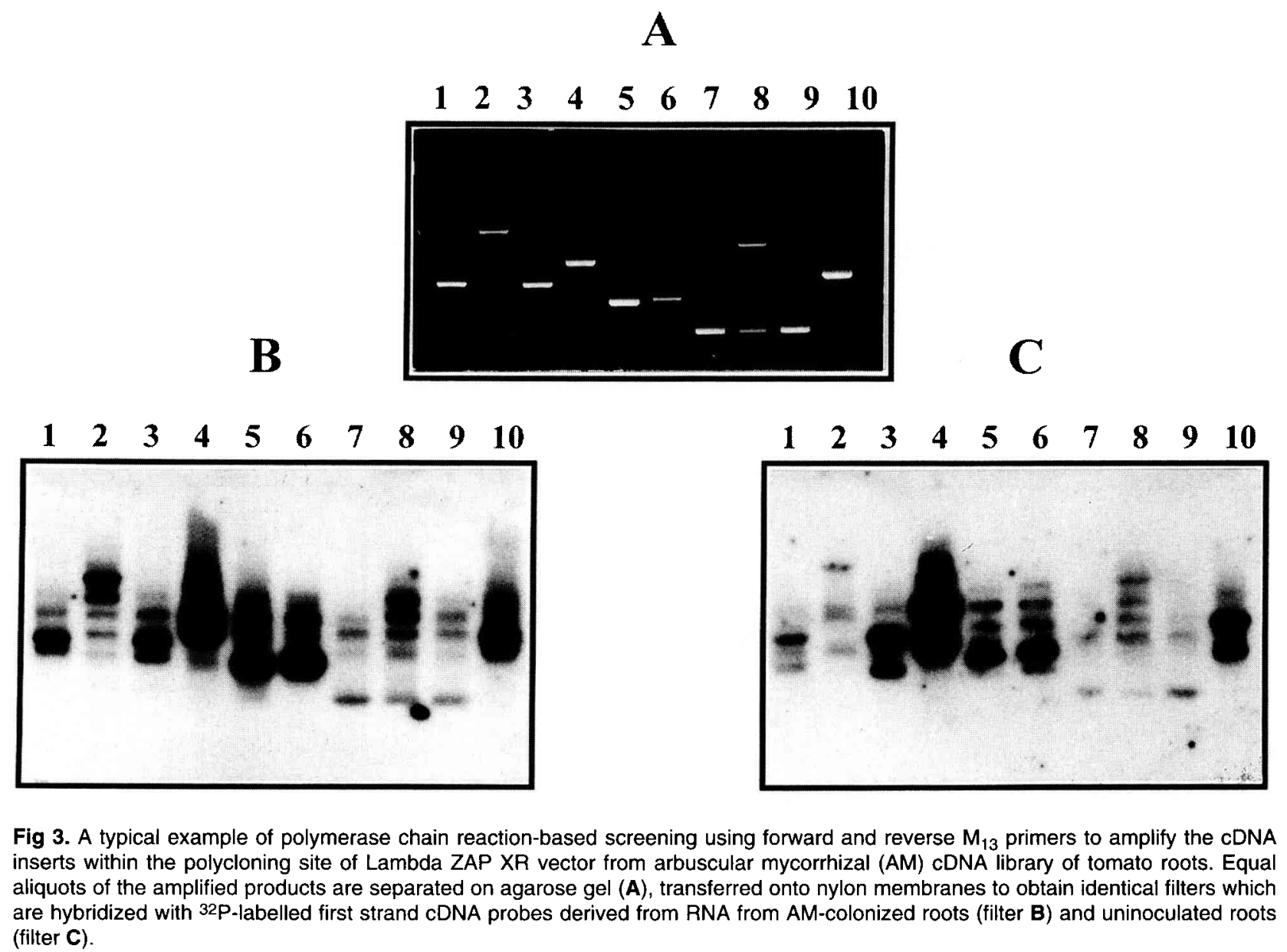


nized roots in comparison to the hybridization signal obtained with cDNA probes of control roots. These clones, therefore, should represent genes whose transcriptional activity was enhanced in tomato roots during AM association. Similar results were obtained with clones 5 and 6 , although the hybridization signal intensity seemed to indicate that these genes were less transcriptionally active in $\mathrm{AM}$-colonized roots than clones 1,2 and 8. The intensities of the hybridization signals obtained with clones $3,4,7$, 9 and 10 did not reveal any differences when probed with cDNA of either AM-colonized or control roots, so the PCR-based screening of these clones was not conclusive with regard to their differential expression in AM-colonized roots.

The PCR products obtained from phage DNA of genes putatively repressed in roots during $A M$ association gave single bands of different molecular weight, which indicated that the isolated clones were likely to be single and different from each other (fig 4A). The hybridization of the replica membranes with radiolabelled first strand cDNA prepared from RNA isolated from AM-colonized (fig 4B) or control roots (fig 4C), confirmed that clone 6 was repressed in tomato roots during AM association, whereas the hybridization signals produced by all of the other clones were weak and seemed not to be significantly different with either probe.

\section{Sequence analysis of differentially expressed clones}

The differentially isolated phage clones from the AM-derived CDNA library were in vivo excised, and the packaged phagemids recovered, purified and transformed back into XL1 blue MRF for storage and sequencing. At least five bacterial colonies were selected from each clone, their plasmid DNA purified and sequenced. From PCR-based screening four clones seemed to be upregulated in tomato roots colonized by AM fungus, and one clone seemed to be repressed during the same interaction. Each clone was sequenced from both the $5^{\prime}$ and $3^{\prime}$ ends using $M_{13}$ forward and reverse primers, and from the sequences obtained, internal oligonucleotides were designed to determine the remainder of the sequences. The sequences were manually processed to remove vector sequences from both ends and to decide where to terminate the sequences. Each of the edited sequences was compared to the nucleotide and protein sequences databases by BLASTN (nucleotide homology) and BLASTP (deduced amino acid sequence homology) searches (Atschul et al, 1990). The results of the searches using sequences of the individual clones with homology to known sequences in the databases are listed in table I.

\section{Isolation of repressed genes}
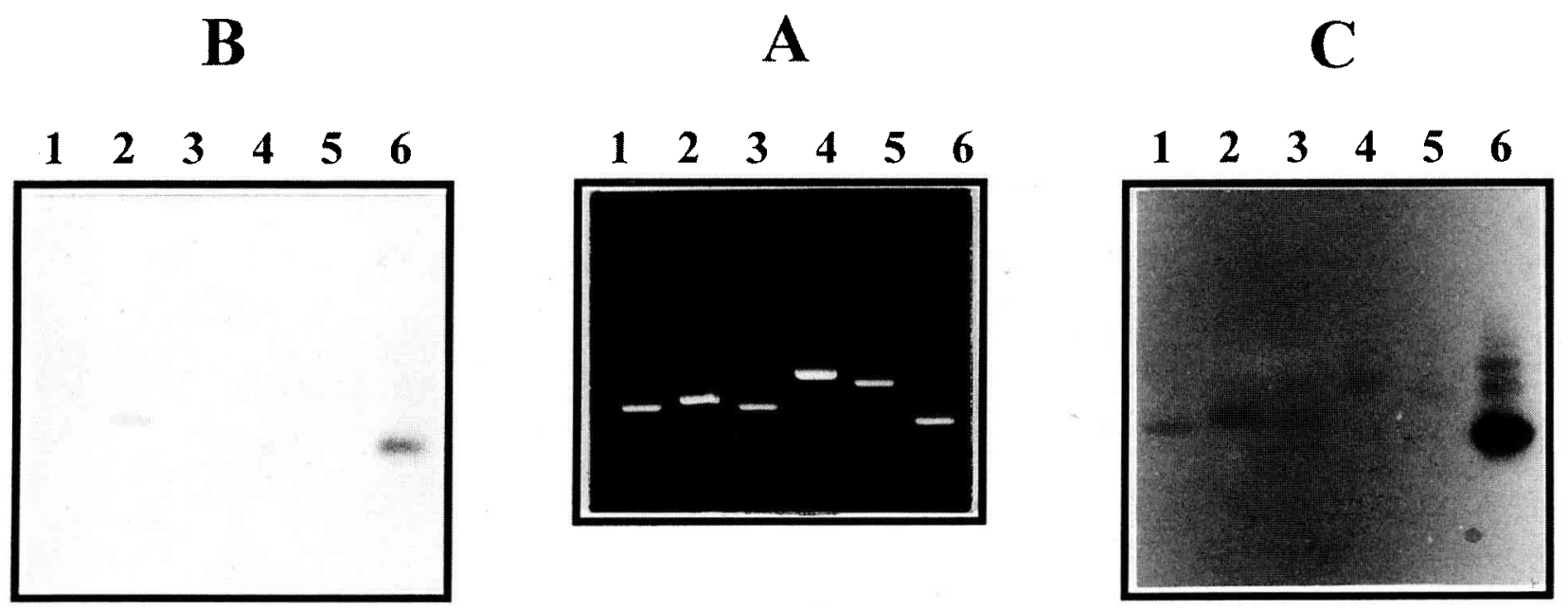

Fig 4. A typical example of polymerase chain reaction-based screening using forward and reverse $M_{13}$ primers to amplify the cDNA inserts within the polycloning site of Lambda ZAP XR vector from cDNA library from uninoculated tomato roots. Equal aliquots of the amplified products are separated on agarose gel (A), transferred onto nylon membranes to obtain identical filters which are hybridized with ${ }^{32}$ P-labelled first strand cDNA probes derived from RNA from AM-colonized roots (filter B) and uninoculated roots (filter C). 
Table I. List of identified arbuscular mycorrhizal (AM) associated genes.

\begin{tabular}{|c|c|c|c|c|}
\hline Clone & Size $(n t)$ & Induction/repression & Sequence homology & Putative protein \\
\hline $\mathrm{Ml}-4$ & 451 & $\begin{array}{c}\text { Induced by AM fungus } \\
G \text { mosseae }\end{array}$ & $\begin{array}{l}95 \% \text { similarity to an induced } \\
\text { gene in tomato root giant cells } \\
\text { infected by the nematode } \\
M \text { incognita } \\
\text { (acc no L24003) }\end{array}$ & Ribosomal protein \\
\hline $\mathrm{MI}-13$ & 2700 & $\begin{array}{l}\text { Induced by AM fungus } \\
G \text { mosseae }\end{array}$ & $\begin{array}{l}66 \% \text { similarity to cul-I gene } \\
\text { from } H \text { sapiens } \\
\text { (acc no U58090) }\end{array}$ & Cullin protein family \\
\hline $\mathrm{MI}-3$ & 751 & $\begin{array}{c}\text { Induced by AM fungus } \\
G \text { mosseae }\end{array}$ & $\begin{array}{c}60 \% \text { simiarity to Eli3 gene from } \\
P \text { crispum recently identified as } \\
\text { a mannitol dehydrogenase } \\
\text { (acc no } \times 67816)\end{array}$ & Mannitol dehydrogenase \\
\hline Ml-1 & 2300 & $\begin{array}{l}\text { Induced by AM fungus } \\
G \text { mosseae }\end{array}$ & $\begin{array}{l}78 \% \text { similarity to PEPC from } \\
\text { nodules of } M \text { sativa } \\
\text { (acc no M83086) }\end{array}$ & PEPC \\
\hline MR-1 & 300 & $\begin{array}{c}\text { Repressed by AM fungus } \\
\text { G mosseae }\end{array}$ & $\begin{array}{l}\text { No significant similarity to } \\
\text { sequences in the databases }\end{array}$ & Not yet known \\
\hline
\end{tabular}

MI: mycorrhizal induced genes; MR: mycorrhizal repressed gene; nt: nucleotides; PEPC: phosphoenolpyruvate carboxylase.

\section{DISCUSSION AND CONCLUSION}

The results of the non-targeted screening approach revealed that the upregulated genes identified in the AM-colonized root library were heterogeneous, and represent different families of genes and proteins. An understanding of the role of these genes will provide valuable insight into the metabolic changes occurring in AM-colonized roots, and the beneficial effect of mycorrhizae on plants.

Clone Ml-4 has $95 \%$ similarity at the nucleotide level with a gene which was identified in tomato root giant cells infected with the parasitic nematode Meloidogyne incognita (Bird and Wilson, 1994). The highest similarity score of the $\mathrm{Ml}-4$ clone to the one identified in tomato roots infected by $M$ incognita indicated that it was probably of plant and not fungal origin. The longest open reading frame of Ml-4 encoded a protein of 89 amino acids, which showed $62 \%$ identity to a 29S human ribosomal protein. Northern blot analysis (not shown) indicated that the MI-4 transcripts were weakly detected in non-mycorrhizal roots but their accumulation was very high in roots colonized with AM fungus. Interestingly, the
MI-4 transcripts were not detected in leaves from either AM-inoculated or control plants, indicating that the expression of Ml-4 was specific to root.

Clone Ml-13 was partially sequenced from the 5' and 3' ends, and approximately 2200 nucleotides were determined out of 2700 . The sequence has $66 \%$ similarity with human cul-1 gene and cul-4 from the nematode Caenorhabditis elegans, which are members of a conserved gene family designated cullins, with at least five members in the nematode $C$ elegans and six in human (Kipreos et al, 1996). It has been shown that the cul-1 gene was a negative regulator of the cell cycle and was also required for proper cell size regulation (Kipreos et al, 1996). Our observations that a cullin-like gene (MI-13) was upregulated in tomato roots colonized by AM fungus suggested that it may have a role in inhibiting cell division and/or controlling the size of cortical cells which are colonized by arbuscular hyphae and have a high metabolic activity. The data available so far are not enough to make conclusions about whether the gene is from plant or fungal origin. However, the results available from research on animal systems together with further investigations in this system 
will provide insights to decipher the biological function of the Ml-13 gene during AM association.

Clone Ml-1 was partially sequenced. Comparison of 800 nucleotides from the 5 ' end showed $92 \%, 85 \%$ and $78 \%$ similarities, and $85 \%, 63 \%$ and $43 \%$ identities with phopsphoenolpyruvate carboxylase (PEPC) from tobacco, potato and nodules from alfalfa roots, respectively. Therefore, it is likely that the Ml-1 clone encodes a phosphoenolpyruvate carboxylase. Since, the MI-1(PEPC) clone was isolated from a cDNA-root library it probably represents a $\mathrm{C}_{3}$ plant type PEPC. Several functions have been suggested for PEPC in $\mathrm{C}_{3}$ plants (Lazko and Kelly, 1983), but a clearly defined function for the enzyme has been demonstrated only in legume root nodules where it plays a significant role in the nitrogen fixation (Pathirana et al, 1992). Our observation that PEPC was probably induced in another type of symbiotic association involving an $A M$ fungus and tomato roots suggested that the enzyme may play a major role in carbon metabolism, mainly carbon dioxide fixation during AM association.

Clone MI-3 was fully sequenced in both directions; it was 751 nucleotides long including the polyA tail. Comparison with other sequences in the databases using the BLAST search (Atschul et al, 1990) revealed that the Ml-3 clone has approximately $60 \%$ similarities with both Eli3 pathogenesis-related genes from parsley (Petroselinum crispum) and a mannitol dehydrogenase from celery (Apium graveolens) (Williamson et al, 1995). From the alignment of the three sequences it appeared that MI-3 sequences did not represent a full length clone, and is probably missing around 300 nucleotides from the $5^{\prime}$ end. The translation of both strands in the six reading frames showed that one open reading frame has $51 \%$ identity with the mannitol dehydrogenase (MTD) from celery. These comparisons suggest that the Ml-3 clone may encode a MTD. Preliminary results from Northern blot analysis (not shown) revealed a weak accumulation of transcripts detected by the Ml-3 probe in AM-colonized roots, while no transcripts were detected in control roots. It is known that fungi can utilize mannitol as a carbon and energy source; therefore we can hypothesize that its oxidation by MTD to mannose can be a process through which the plant regulate the mannitol pool size, a mechanism that might control the invasion of the fungal symbiont. The upregulation of MTD might also allow access to mannitol as an added carbon and energy. This might be advantageous in AM-colonized roots to support the increased demand of carbon and energy for both partners.

Finally, the MR-1 clone represented a gene isolated from the library prepared from mRNA of control roots, which was downregulated during AM association. This clone was only 300 nucleotides long and was fully sequenced in both directions. After a search using BLAST, no significant homology was found in the databases. Further investigations are now in progress to isolate other longer, related clones in order to determine the putative protein they might code for.

The non-targeted differential screening of these cDNA libraries of AM-colonized and control tomato roots identified at least four upregulated genes and one downregulated gene. The comparison of the clones identified with other known genes in the sequence databases revealed some interesting and significant similarities. The cloned genes seemed to encode proteins which were involved in various metabolic pathways, including carbon dioxide fixation, sugar metabolism, protein synthesis and cell size as well as cell cycle control. The identification of the genes differentially expressed in AM-colonized roots will allow us to gain a thorough understanding of the mechanisms that control AM symbiosis.

\section{ACKNOWLEDGMENTS}

We thank M Perry for her technical assistance. This work is currently supported by a European Union (EU) grant (no AIR 3-CT 94-0809).

\section{REFERENCES}

Altschul SF, Gish W, Miller W, Myers EW, Lipman D (1990) Basic local alignment search tool. J Mol Biol 215, 403-410

Bird DM, Wilson MA (1994) DNA sequence and expression analysis of root-Knot nematode-elicited giant cell transcripts. Mol Plant-Microbe Interact 3, 419-424

Gurr SJ, McPherson MJ (1992) PCR-directed CDNA librarie. In: Molecular Plant Pathology: A Practical Approach, Vol 1 (SJ Gurr, MJ McPherson, DJ Bowles, eds), IRL Press, Oxford, UK, 147-170

Harley JL, Smith SE (1983) Mycorrhizal Symbiosis. Academic Press, London, UK

Harrison MJ (1996) A sugar transporter from Medicago truncatula: altered expression pattern in roots during vesicular-arbuscular (VA) mycorrhizal association. Plant J 9, 491-503 
Harrison MJ, Van Buuren ML (1996) A phosphate transporter from the mycorrhizal fungus Glomus versiforme. Nature 378, 626-629

Lazko E, Kelly GJ (1983) The many-faceted functions of phosphoenolpyruvate carboxylase in C3 plant. Physio/ Veg 21, 805-

Kipreos ET, Lander LF, Wing JP, He WW, Hedgecock EM (1996) cul-1 is required for cell cycle exit in $C$ elegans and identifies a novel gene family. Cell 85 , 829-839

Martin-Laurent FA, Franken P, Gianinazzi S (1995) Screening of cDNA fragments generated by differential RNA display. Ann Biochem 228, 182-184

Newman El, Reddell P (1987) The distribution of mycorrhizas among families of vascular plants. New Phytol 106, 745-751

Pathirana SM, Vance CP, Miller SS, Gantt JS (1992) Alfalfa root nodule phosphoenolpyruvate carboxylase: characterization of the cDNA and expression in effective and plant-controlled ineffective nodules. Plant Mol Biol 20, 437-450
Sambrook J, Fritsch EF, Maniatis T (1989) Molecular Cloning: A Laboratory Manual. Cold Spring Harbor Laboratory Press, Cold Spring Harbor, NY, USA

Trouvelot A, Kough JL, Gianinazzi-Pearson V (1986) Mesure du taux de mycorrhization d'un système radiculaire. Recherche de méthodes d'estimation ayant une signification fonctionnelle. In: Physiological and Genetical Aspects of Mycorrhiza (V Gianinazzi-Pearson, S Gianinazzi, eds), INRA Press, Paris, France, 217-221

Vivienne-Gianinazzi P, Dumas-Gaudot E, Gollotte A, Tahiri-Alaoui A, Gianinazzi S (1996) Cellular and molecular defence-related root responses to invasion by arbuscular mycorrhizal fungi. New Phytol $133,45-57$

Williamson JD, Stoop JMH, Massel MO, Conkling MA, Pharr DM (1995) Sequence analysis of a mannitol dehydrogenase cDNA from plants reveals a function for the pathogenesis-related protein ELI3. Proc Natl Acad Sci USA 92, 7148-7152 